\title{
Henrietta Mondry
}

\section{Glasnost in Soviet literary criticism: current debates on the Russian national character (1988-1990)1}

\begin{abstract}
Re-evaluation of the cultural heritage of the past has been an integral part of Soviet literary criticism. From 1987 up to the present, literary criticism has played a leading role in the promotion of the economic, social and political reforms of perestroika. Literary critics use the methodology of social deconstruction in the interpretation of the literary texts of the past, actualising the problematics of the texts in accordance with their relcvance to contemporary Soviet issues.
\end{abstract}

1. The re-evaluation of the literary heritage and the search for a national typology

\subsection{Delimitation and aim}

The aim of this article is to demonstrate how the cultural cliches borrowed from nineteenth-century Russian literature form an important part in today's Glasnost debates on the topic of national character. In particular, the polemics in literary periodicals dealing with the rise of Russian self-awareness in the period 1988-1990, as well as the role played in the discussions by the interpretation of literary works will be traced.

In his essay "Russian past and Soviet present", Alain Besançon (1984) speaks of two types of links which Soviet Russia has with its historical past: 'normal' links and 'extraordinary', or 'abnormal' links. By 'normal' links, Besançon understands the inherited geography, territory, and population; by 'extraordinary, the searching through of past history for explanations of present misfortunes, and the exploitation of history for whatever political or ideological discussions are taking place in the Soviet Union, especially when the arguing parties cannot reach an agreement.

The Soviet attitude towards its cultural heritage follows the same pattern, especially in the attitude towards Russian literature. The re-evaluation of the literary heritage has always constituted an important part of the ideological life of official literary criticism. Lenin's formula in "Leo Tolstoy as a mirror of the Russian Revolution" (1907), according to which any great artist depicts the class struggle and political reality in his work, even if independently of his own will, together with Plekhanov's well-known formula of otsyuda

\footnotetext{
The research reported in this paper was supported by grants from the Federal Institute for Soviet and International Studies at Cologe and from the Institute for Research Development of the Human Sciences Research Council.
} 
and dosyuda ('from here and up to here'), served as the methodological bases for the 'extraordinary', or 'abnormal' attitude to the literary past.

\section{Influence of the past}

Glasnost in literary criticism has only reaffirmed Besançon's formula. The ideological and economic polemics which have been crowding the pages of the 'heavy' literary journals in the last three years have centred around the 'returned names' and 'blank spots' of Russian literature of the past. In the eternal polemics of Klassiki $i$ my (We and the classics), also the Russian classics are once more being dragged into today's philological wars, to use the phrase of Yury Loshchits, editor-in-chief of Literaturnaya Rossiya. A reprint of the infamous discussion "We and the classics" was published in Moskva (1990, Nos. 1, 2, 3), and articles with titles like "What did Gogol believe in?" (Astafiev, 1990:183), "A lesson from the classics: Dostoevsky and modernity" (Tarasov), "Dostoevsky and the canon of the 21st century" (Karyakin, 1989:239-240), and "Vasily Vasil'evic Rozanov" (Nekolyukin, 1990), have flooded today's literary market in the Soviet Union.

This unchanging adherence to the classics remains unshattered even by the most recent publications of the 'new prose' writers, who openly challenge the moral, didactic and spiritual values of 19 th century Russian literature. In his "Manifesto of the "new prose", Varlam Shalamov (1989:253) accused Russian literature of the second half of the 19th century of spilling human blood of the 20 th century. He writes:

Russian writers - the humanists of the second half of the nineteenth century - bear on their conscience the great sin of human blood which was spitt under their banner in the twentieth century. All the terrorists were Tolstoyans and vegetarians, all the fanatics were disciples of the Russian humanists. They cannot atone for that sin through prayer. ${ }^{2}$

In his letter of 24 March 1968 (to the mathematician I.A. Gel'feld), Shalamov also mentioned the unusual role literature plays in Russian society, by stating that literature is expected to solve problems which could and should be solved by science only. $\mathrm{He}$ also stated that Russian literature of the second half of the nineteenth century produced moral clichés (shtampy) which have continued to rule Russian social life up to now. One such important moral cliche is "the duty to improve people"3 (Shalamov, 1989:232).

\section{3 'Blank spots' in Russian literature and history}

Shalamov was not the first to accuse Russian literature of a destructive role in Russian history. Vasily Rozanov, in his Apocalypses of our time (1917, 1918), referred to Russian literature as 'such muck' (takaya gadost), which, together with "all those Hertzens and Belinskys" (i.e. literary critics and journalists), made any constructive work on behalf of the Russian tsar impossible. Russian literature thus paved the way to the Revolution, the 'apocalypsis' of Rozanov's times.

\footnotetext{
2 "Russkie pisateli - gumanisty noroy poloviny XIX veka - nesut na dushe velikiy grekh chelovecheskoy krovi, prolitoy pod ikh znamenem $\vee \mathrm{XX}$ veke. Vse terroristy byli tolstovtsy i vegetariantsy, vse fanatiki - ucheniki russkikh gumanistov. Etot grekh im ne zamolit."

3 "Poleznoe delo uluchsheniya lyudey".
} 
Today, both Shalamov's and Rozanov's works have been made available again to the Soviet reader. Together with such writers and thinkers as Merezhkovsky, Fedotov, Solov'ev, Bulgakov, and Berdyaev, they form an ill-assorted collection of belye pyatna (blank spots) in the history of Russian culture and literature. The list is curious in that humanists are placed side by side with the 'underground men', Rozanov and Shalamov. The list becomes even stranger in the hands of contemporary literary critics, who make the names part and parcel of what is called the 'contemporary literary process', i.e. part of the ideological debates of Glasnost.

Departing from this point of view Russian literature is once more being cast into ideological moulds, and its heroes and heroines are being held up as patterns for imitation, as models for perfection. Indeed, a call has been made for the need to use literary theory to enable parallels to be drawn with contemporary situations, and in so doing to actualise the written texts of the past:

We still don't have anything close to a literary theory which would prove to have the strength to give responsibly and distinctly a conception of the actuality of artistic works of the distant and relatively ncar past. The new times have caught us unawares ... ${ }^{4}$ (Turbin, 1989:258).

The tendency to treat literary texts as a source of scientific knowledge of political and socio-economic matters remains intact:

The necessity to resort to the classics is bcing experienced more and more strongly, and our eternal fellow-travcllers are becoming a distinctive group of experts and consultants on the most important problems surrounding the aesthetics and ethics of social existence. ${ }^{5}$ (Turbin, 1989:258.)

Today's literary critics, embroiled in their ideological polemics, seem unaware of the anachronistic character of their activities. ${ }^{6}$ Most critics use in their arguments and counterarguments literary allusions, the names of literary characters, and quotations from nineteenth-century literary texts and early twentieth-century philosophical texts: this is true both of the 'Westernisers' and adherents of 'pan-humanism' (gathered around Novy Mir, Znamya, Oktyabr', Literatumaya Gazeta), as well as of the pochvenniki (of the 'back-to-thesoil' movement), and the samobytniki (originators) of Molodaya Gvardiya, Moskva, Nash Sovremennik, and Literatumaya Rossiya. At the centre of these polemics is the theme of the Russian national character.

Although Glasnost has eliminated censorship and marginalised the application of the Plekhanov formula otsyuda i dosyuda in the evaluation of the cultural heritage of the past, self-censorship continues to manifest itself in the choice of texts published in the major literary journals.

\footnotetext{
4 -U nas vse eshche net i polunameka na literaturnovedcheskuyu tcoriyu, kotoraya okazalas' by $v$ silakh otvetsvenno, vnyatno dat' kontseptsiyu aktual'nosti khudozestvennykh proizvedeniy dalekogo i otnositel'no blizkogo proshlogo. Novye vremena zastayut nas v rasplokh....

5 "Neobkhodimost' pribegnut' $k$ klassike ispytyvaetsya vse sil'nee, i vechnye sputniki nashi stanovyatsya svocobraznoy gruppoy eksperiov, konsul'tantov po vazhneyshim voprosam estetiki i etiki social'nogo byilya."

${ }^{6}$ As an example of literary criticism closer to actuality, one should mention a series of articles on Pushkin and contemporary Russian sclf-awareness of the messianic trend. See Nepomnyashchiy (1990:6).
} 


\subsection{The Russian national character}

Not only the samobytniki of the Rasputin and Safarevich brand, or the authors of the "Letters to Russian writers" (Pis'mo pisateley Rossii ${ }^{7}$ ), but also the obshchie cheloveki, the 'panhumanists' of Novy Mir, select texts which address the issue of the 'Russian soul' and the 'Russian national character'. If we look at the contents of Novy Mir of 1989 and 1990 under the rubric "From the history of Russian social thought", we find a persistent interest in the Russian character and the Russian soul: Bulgakov's "My Motherland" (1989:188236), Solov'ev's "Towards a characterisation of the Russian mind (1990:200), Rozanov's "The Russian Nile" (1989:220), to name just a few. During 1989 and 1990 Voprosy Literatury, in the section "From the history of Russian overseas literary scholarship", also selected publications on the theme of the Russian national character, especially those with a metaphysical flavour: Fedotov's "Articles on culture" (1990:), Berdyaev's "On the religious significance of Leo Tolstoy" (1989:), Mochul'sky's chapter from The Spiritual Path of Gogol (1989), Leont'ev's work on Tolstoy (1989:188-238; 1990:200-236), Merezhkovsky's essay "M. Yu. Lermontov - a poet of supermanhood" (1989). Not to be forgotten is the current re-publication of essays from Vekhi in Literatumoe Obozrenie, $(1990(8,9,10,11)$ ).

Strangely enough, the 'Shalamov-Rozanov' view on Russian literature as instrumental in the coinage of ideological beliefs and moral clichés in twentieth-century Russian society continues to be applicable to Glasnost times. Contemporary warring camps of seemingly diverse traditions - the Westernisers and Slavophiles - have found one common point of interest: the Russian national character. And it is nineteenth-century Russian literature which serves as the common ground for the reconciliation of interests. The same literary tradition which, in the Shalamov-Rozanov view, was responsible for the Russian Revolution and the more than 70 years of Soviet power, and which was further made ideologically respectable with the help of a methodology borrowed from Lenin's "Leo Tolstoy as a mirror of Russian revolution", continues to define Glasnost ideology on the pages of the thick literary journals. This was noticed by Yu. Shreyder in "Consciousness and its imitation" (1989), where he speaks of "the total ideologisation of consciousness"8 and the role which common reading sources can play in forming the ideological beliefs which subsequently rule society.

Shreyder (1989:114-118) warns that literature should not be treated as a science, that it does not possess the istina, the truth, or the 'world formula'. But this lone voice remains unheard by the army of Soviet literary critics. Both camps constituting the 'literary struggle', i.e. the ideological battlefield around Russia's future and its past, proclaim themselves to be followers of the 'humanistic traditions' of Russian literature. The signatories to the "Letter to Russian writers", and the authors of the almanac Aprel and their followers, would all have to admit to being brought up on the same ideals, namely those dubbed obshchechelovecheskie (panhuman), in Glasnost terminology.

\footnotetext{
${ }^{7}$ Liseratumaya Rossiya published this letter, signed by 74 Russian writers, in its issue of 2 March 1990. Litenoturnaya Gazeta then answered with 75 signatures on 7 March 1990, after which on 12 March 1990 Literatumaya Rossiya started a new section called "In support of the letter to the Russian writers" ("V podderzhku pis'ma pisately Rossii").

8 "total'naya ideologizatsiya soznaniya"
} 
'Literariness' manifests itself even in the Letter to Russian writers. The signatories rebelled against applying to the Russian national character such characteristics as Sharikov's children (deti Sharikova), 'Russian soul - a thousand-year-old slave' (russkaya dusha tysyacheletnyaya raba) - all of which are products of literary typology, i.e. of Mikhail Bulgakov's "Heart of a dog" (Sobach'e serdtse) and Vasily Grossman's "Life and fate" (Zhizn' $i$ sud'ba). At the same time they use as their argument against the 're-writing of Russian history' the true patriotism of such eyewitnesses of Russian history as Pushkin's "To the slanderers of Russia" (Klevetnikam Rossii) and Leo Tolstoy's War and Peace.9

\subsection{Acceptance of the metaphysica}

Earlier, mention was made of the absence of any understanding of the concept of anachronism in today's reading of the 'returned texts'. This is particularly striking in the interpretation of the works of metaphysical, religious thinkers. Particularly astonishing is the apparent readiness by Soviet critics to accept such categories as dusha or dukhovnoe (soul or spiritual) in their primary, non-metaphorical meaning. It is as if 70-odd years of atheistic education, during which atheism was an examinable university subject, have vanished overnight in order to bring today's literary critics into the company of Berdyaev, Fedotov, and Merezhkovsky. Even the social and scientific Christianity of Fedorov, the only non-atheist philosophical teacher in Soviet literature, is no longer dubbed utopian.

\section{Today's 'Men of the eighties' in Soviet literary criticism}

The anachronism of the integration of the old into the new culture is accompanied by a replay of past literary struggles. Today's critics even like to call themselves 'men of the eighties (vos'midesyatniki) and 'men of the sixties' (shestidesyatniki), as in the last century. They continue to use Aesopian language, literary allusions, and the technique of intimidating impersonated polemics which are borrowed from those enfants terribles, Pisarev, Dobrolyubov, and Chernyshevsky. And although censorship, which caused the nineteenth-century critics use of literary allusions as a means of concealing contemporary problems, has been officially abandoned, Soviet literary critics today still employ the technique of allusions, codes and ciphers (Chuprinin, 1989).

Soviet literary critics themselves are aware of the anomalous and very specific role they play, as can be illustrated by the questionnaire on the role of literary criticism which was published in Moskva, (1990:190-201). In the questionnaire the following is asked: "What is the role of literary criticism in the contemporary literary process in comparison to that of the preceeding years?"10 The responses include the following statements:

- $\quad$ "Criticism is lapsing into social and political journalism" (Zolotussky). ${ }^{11}$

\footnotetext{
${ }^{9}$ See Literatumaya Rossiya 1990, No. 9.

${ }^{10 m}$ Kakova rol' literaturnoy kritiki $v$ sovremennom protsesse po sravneniyu $c$ predshestvuyushchimi godami?"

${ }^{11 " K r i t i k a ~ u k h o d i t ~ v ~ p u b l i t s i s t i k u " ~}$
} 
- "Having armed itself with social and political journalism and having taken over its instruments and experience, criticism will clearly make headway"12 (Kurbatov).

- "We don't have any aesthetic criticism at all. What we have at the moment is powerful political and social journalism parading as criticism"13 (Gusev).

- "Our discussions on literary criticism look like the discussions of political scientists ${ }^{14}$ (Sinel'nikov).

- "Literary work is treated not as an object of criticism, but merely as a conduit for 'popular propaganda"'15 (Glushkova).

The most perceptive answer, however, is given by Lev Annensky:

In comparison to previous years, the very future of literary criticism should be put into doubt. Western type cultures do not know such a phenomenon; they don't have 'literary critics', but rather 'liter ary historians' or 'reviewers'. If political thinking as such continues to be upheld in Russian culture, and literature proves unable to fulfil this role by obligation, then the whole of Russian mentality can change, and then literary criticism will lose its niche. ${ }^{16}$

Apart from its sociologically oriented pro-perestroika vocabulary, this answer is less banal than it might seem, for it openly introduces the fuzzy and unscientific notion of the 'Russian mentality' (russkaya mental'nost'). This notion is the meeting point of literature and contemporary ideological trends, and thus it overcomes the problem of anachronism. It is the notion of the Russian national character which actualises so painlessly the thinking (anachronistic in any other culture) of the newly returned metaphysical writings of the past, with their dukhovnost' (spirituality) and dusha (soul). And it is here where the literary typology of Russian culture appears to be crucial for the understanding of today's literary process and the ideological trends which underlie it.

Georgy Fedotov, whose work is now being re-accepted, understood the centrality of the typology of nineteenth-century literature. In his "Articles about culture", written in the 1930's, we read: "For the huge masses of readers which make up the reading market, the only literature which exists is that of the nineteenth century"17 (Fedotov, 1990:215).

\footnotetext{
12"Vooruzhivshis' publitsistikoy, i perenyav u nee instrument i opy, kritika yavstvenno vykhodit vpered."

${ }^{13}$ Khudohzestvennoy kritiki u nas voobshche net. U nas seychas sil'naya publitsistika $v$ forme literaturnoy kritiki." of political scientists"

${ }^{14}$ "Literaturno-kriticheskie diskussii pokhodyat u nas na diskussii politologor".

${ }^{15}$ "Literaturnoe proizvedenie vystupaet ne ob"ektom kritiki, a lish' povodom dlya 'populyarnoy propagandy".

16"Po sravneniyu s predydushchimi godami voznikaet somnenie $v$ samom budushchem literaturnoy kritiki. Kul'tury zapadnogo tipa ne znayut takogo fenomena; tam 'literaturnoy kritiki' net, est': 'istoriki literatury' i 'retsenzenty'. Esli v russkoy kul'ture utverditsya politicheskoe myshlenie, kak takovoe, i literature ne pridetsya vypolnyat' etu rol' po perechisleniyu, togda vsya russkaya mental'nost' mozhet izmenit'sya, i togda literaturnaya kritika utratit nishu".

${ }^{17}$ Dlya ogromnykh mass chitateley, opredelyayushchikh knizhny rynok, drugogo iskusstva krome iskusstva XIX veka, ne sushchestruet."
} 
Today, Anna Latynina reaffirms the line of dependence between nineteenth-century Russian literature and what she calls 'catacomb culture' (katakombnaya kul'tura). Official literature and 'catacomb literature', however, share the same nineteenth-century typology:

\begin{abstract}
The culture which we here have up to now called 'catacomb culture', was usually reckoned as 'foreign', juxtaposed to that liberating line which we draw from Pushkin to Gor'ky, from the Decembrists to the Bolsheviks. But the line from Pushkin, who glorified freedom and charity, from Dostoevsky, who stood on the Semonov piazza in the shirt of a condemned man, from Vladimir Solovev, who appealed to the tsar to pardon the assasins, from Tolstoy, who raised his voice against executions, is drawn not to those who sang the praises of the grandiose construction of the Belomor canal, but rather to those who dug the earth in that canal with their hands, more used to the pen than to the shovel, who weren't tempted by the bribes of the Grand Inquisitor, who always remembered the spiritual essence of man ... ${ }^{-10}$ (Latynina, 1990:249).
\end{abstract}

Latynina insists on the existence of official and non-official (catacomb) cultures in the Soviet Union, but at the same time makes a point which is of interest to us here, that both these cultures had the same source, namely nineteenth-century literature.

\title{
2.1 Line of continuity
}

The line of continuity between the nineteenth-century literary scene and contemporary ideological debates is also broached by the writers published in Nash Sovremennik ("Our contemporary"), such as Taisiya Napolova (1990:177). This critic chooses to state the problem as the 'Succession of evil' (Preemstvennost' zla), and then goes on to transfer the ideological battles of the nineteenth century into today's polemics. She simplistically divides the last century's authors into two groups: "Russophobes of the last century" i.e. "radical liberals" and ... "the leading social thinkers in Russia". Under the latter umbrella she puts Dostoevsky, Leskov, Bunin, Tolstoy, Korolenko, Strakhov, etc. whom she calls the "best minds of Russia" (luchshie umy Rossii) (p. 177). These are all put in opposition to Chaadaev who "flogged Russian history" (vysek russkuyu istoriyu) (p.186). The critic advocates the ideal of continuity (preemstvennost') with the good traditions of nineteenthcentury Russian literature, such as Dostoevsky's ideas of universality (vsemimost') and panhumanity (vsechelovechnost'), and Rozanov's compassion (sostradanie), which she views as the characteristic feature of the "national self-consciousness of a people" (natsional'noe samosoznanie naroda) (p. 188).

\subsection{Role of literary typology}

The problem surrounding the role played by literary typology in the formation of the literary consciousness of today's mass culture in the Soviet Union is addressed by Sergey Zenkin's article "Is the sacred really sacred?" (Zenkin, 1990). Zenkin explains the cultural stereotypes of modern Russian consciousness by what he calls the 'anthropocentric'

\footnotetext{
${ }^{18 n} \mathrm{Kul}$ 'turu, kotoruyu my imenovali zdes' katakombnoy, do poslednego vremeni u nas bylo prinyato schitat' 'chuzhoy', protivostoyashchey toy osvoboditel'noy linii, kotoruyu vystraivaem ot Pushkina do Gor'kogo, ot dekabristov do bolshevikov. No skoree liniya of Pushkina, vosslavivshego svobodu of Dostoevskogo, stoyavshego na semenovskom platsu v rubakhe smertnika, of Vladimira Solov'eva, pricyvavshego tsarya pomilovat' tsareubits, of Tolstogo, vozvyshivshego golos protiv kazney, tyanctsya ne $k$ tem, kto vosslavil grandioznoe stroitel'stvo Baltiyskogo kanala, no $k$ tem, kto dolbil grunt na etom kanale rukami, bolee privychnymi $k$ peru, chem $k$ lopate, kto ne soblaznilsya posulami Velikogo Inkvizitora, kto pomnil o dukhovnoy sushchnosti cheloveka."
} 
character of both Russian nineteenth-century literature and the modern view of it. Literary rypes were important both for their creators and their commentators: "Up to this very day, as in the days of Belinsky and Dobrolyubov, our critics incessantly advocate typical characters, taken straight from life"'19 (Zenkin, 1990:89).

To speak about literature means to speak about literary characters. These literary characters then are judged, imitated, or dismissed as fallen idols, depending on the ideological trends of the times. This anthropocentric attitude towards literature demonstrates itself not only in the treatment of literary types, but also in attitudes towards their creators, i.e. the writers and poets themselves. Zenkin (1990:93) even warns that a real danger exists that a certain social group of people could today be blamed by the ideologues-administrators for certain economic misfortunes, on the basis of literary typology:

I even suspect that literary ideological authorities, controlling this 'organized simplification of culture' will be able to find for itself plausible situations that alleviate the guilt ... and explain the disasters common to all people through insufficiencies in the work of some or other social group. ${ }^{20}$

And indeed, if we look at the contemporary literary process, we discover that the struggle takes place around both the literary characters and the historical personalities of the nineteenth century.

\section{Oblomov and a new economic model}

The type blamed under perestroika for the economic collapse of the Soviet Union has been Oblomov. Although this creation of Goncharov does not belong to the 'returned literature', it still plays an important role in the perestroika re-evaluation campaign. Oblomov stands for the sleepy, inert, passive and lazy Russian type. Soviet leaders, starting from Lenin and extending up to Gorbachev, have accused the Russian people of laziness, both physical and emotional. But if Lenin spoke of the peasant class as Oblomovs, then Zaslavskaya, Abalkin and the co-authors of Inogo ne dano (No alternative is given) (Afanasiev, 1988), implied that the Oblomov syndrome was the main stumbling block of perestroika. This time the bearer of the Oblomov syndrome is the estranged and lazy, poorly qualified working class who, instead of being the leaders of the economic reform, became its main hindering force (Zaslavskaya, 1988:30).

It is significant that one of the most popular articles in Voprosy Literatury during the years 1988 and 1989 appears to have been the article devoted to the re-evaluation of Oblomov. This article is entitled "A long experience in sleep. (A reflection on I.A. Goncharov's novel 'Oblomov')" (Kantor, 1989). A sociological questionnaire, conducted among the readers of Voprosy Literatury, showed that the article received a higher score than some formerly censored and hence previously unpublished works (Devyatko \& Sveryev, 1990:14).

\footnotetext{
19n Nasha kritika i po sey den', kak i vo vremena Belinskogo i Dobrolyubova, postoyanno tolkuet o 'tipicheskikh kharakterakh, vzyatykh iz zhizni."
20-Podozrevayu dazhe, chto $i$ literaturno-ideologicheskoe nachal'stvo, upravlyaya etim 'organizovannym uproshcheniem kul'tury', sumeet izyskat' sebe pravdopodobnye, smyagchayushchie vinu obstoyatel'stva... Ob'yasnyat' obshchenarodnye bedstviya 'nedostatkami v rabote toy ili inoy sotsial'noy gruppy")


Kantor's article has the subtitle "A modern reading of the classics". It starts with a polemic against Yury Loshchits's reading (1986:190) of Oblomov as the model of perfection of the Russian national character. In his 1986 monograph, Loshchits had discredited Stoltz as a wandering Jew, as the evil of Russian history. We find in the monograph the following, exemplarily Slavophilic condemnation of Stoltz, the Germano-Russian capitalist:

\begin{abstract}
While the 'Kingdom of Sleep' exists, Stoltz does not, somehow, feel well, even in Paris he cannot find peace and sleep. He is tormented by the thought that Oblomovka's muzhiks have, since the beginning of the world, worked on their little land and harvested its rich crops, and that, without reading agronomic pamphlets of any kind. And he is also tormented by the fact that an excess of bread is left with the muzhiks, instead of being sent along the railway lines to that very same Paris. The 'Kingdom of Sleep' is being destroyed, not because Il'ya Il'yich is lazy and idle, but because his friend is strikingly active. According to Stoltz's will, the 'Kingdom of Sleep' has to become ... a railway station, and Oblomovka's muzhiks should seek employment in it.
\end{abstract}

In contrast, Loshchits presents Oblomov as morally, philosophically, and metaphysically superior to Stoltz, as an ideal Russian character, in fact.

Kantor openly makes the ideological context of his work clear, and declares the making relevant of Goncharov's text to be the main purpose of his research. Predictably, his new interpretation of the novel presents the character of Stoltz as Goncharov's answer to the economic and political problems faced by Russia at the time. Oblomov is ridiculed in the same fashion as he was ridiculed by Lenin, who saw in him the incarnation of inborn Russian idleness and inertia. As a proponent of the 'Russian capitalist line', Kantor (1989:171-172) rehabilitates Stoltz in the following terms:

Why is Stoltz so much disliked? It appears that his sin is one of the most unacceptable for our vulgar sociological science: he, as well as Tushin from The Ravine, is a Russian capitalist, shown from an idealised perspective. But the word 'capitalist' remains for us a swear word.

And further:

Oblomov was a severe warning to the culture, but its contemporaries refused to see it, as they saw the main problematics of the novel to be the description of the passing away of the Russian past. More than a hundred years had to pass, the Revolution had to take place, and the civil war, and Stalin's terror, and decades of stagnation and incrtia, so that the culturological essence of the great novel would become apparent. (Kantor, 1989:148.)

\title{
3.1 Presentation of the Russian archetype
}

At the time when conservatives were replying to Abalkin's accusations about the inertia of the Russian people in articles like "An argument with academician Abalkin about the 'blame of the Russian muzhik'"21), the article "Not sleep but insomnia" (BoranovaGonchenko, 1989:15) had appeared. This article not only entered into literary polemics with Kantor's reading of Oblomov as an archetype of the Russian national character, it also provoked a dispute on the typological approach to Oblomov with one of the leading experts of literary theory, Mikhail Epshtein, as expressed by him in his essay "Sleep and battle" (Epshtein, 1989:31-41).

Epshtein put forward the idea of a symbiosis of Oblomov and Korchagin - 'Oblomagin' - as the archetypal Russian psyche, made up of such polar concepts as complete inertia on the

21"Spor s akademikom Abalkinym o 'vine russkogo muzhika" (Boranova - Gonchenko, 1989a:) 
one hand, and thoughtless fits of activity leading to destruction on the other. Both Kantor and Epshtein are accused of distorting the Oblomov/Stoltz and Oblomov/Korchagin typology, by "qualifying the beginnings of a national archetype to be an illness, which needs urgent treatment from a psychiatrist" (Boranova-Gonchenko, 1989:15).

Baranova-Gonchenko (1989:15) defends Oblomov and the Russian national character as well as, more generally, the theme of 'Russianness' (o nusskom) from attacks from Kantor, Epshtein, Grigory Kanovich and the Brothers Strugatsky - all Jews - with their "sacrilegious attitude towards Russians and the Gospel of St. John".

If the negative part of the national archetype presented by Oblomagin was reduced from the left (by Kantor and Epshtein) and then defended from the right (BoranovaGonchenko), where the defender took up the theme of Russophobia, then the accreditation of the Russian national character with inborn goodness had to come from the metaphysically minded critics.

\section{Nikolay Fedorov and today's search for the 'spiritual'}

The growing search for the mystical and metaphysical, for dukhovnoe, in the 'soul of the nation', can best be illustrated by the reinterpretations of Fedorov's philosophy. Praise for the inborn goodness of the Russian national character in the slavophilic tradition of the nineteenth century had always had strong messianic connotations. These connotations would occasionally acquire militaristic overtones. Thus Dostoevsky (with whom, as today's Soviet critics put it, Russian philosophy commenced ${ }^{22}$ ) started with 'the chosen people' (narod bogonosets) and ended up with 'sooner or later Constantinople must be ours' (Rano ili pozdno Konstantinopl' dolzhen byt' nashim).

If in the 1970's - 1990's it was Dostoevsky's messianism which served as inspiration for the literary critics' attack on Yury Seleznev's Russian nationalism (Mondry, 1989), then in 1990 Fedorov's philosophical tract was chosen to serve a similar function. The very title of this work of Fedorov ("Philosophy of the common task"), contains two main concepts which are symptomatic for today's national awareness: 'common'; and 'task', or 'deed'. With its delo, or activity part, it touches the main painful spot (bolevaya tochka) of today's national crisis the search for a solution to the economic collapse. With its concept of general, or common (obshchiy), it relates both to the crisis of the 'empire' concept, and to the spiritual (dukhovnoe) and consiliatiry (sobornost) aspects of today's metaphysical awareness.

And indeed, we find today's reading of Fedorov in Voprosy Literatury, rather predictable. In the recent article on Fedorov by S. Semenova (1990:96-117), the turn to mysticism, which was not present in her preface to the 1982 edition of Fedorov's collected works, is in the forefront. If in Semenova's work dating the beginning of the last decade the emphasis was placed on the 'scientific' character of Fedorov's social utopia, then in the 1990 article, "A justification of Russia - (An outline of national metaphysics)", we encounter the familiar interpretation of the text with the emphasis placed on national typology.

Semenova ascribes certain features of messianism to Fedorov, who chose the Russian people to carry out the Deed. The Russian people thus are moved to the 'active' side of

\footnotetext{
${ }^{22}$ See Problema vozrozhdeniya russkoy kul'tury in Druzhba norodov.
} 
Semenova ascribes certain features of messianism to Fedorov, who chose the Russian people to carry out the Deed. The Russian people thus are moved to the 'active' side of the Oblomov-Stoltz antithesis, they are reckoned to be the nation of the Deed, thanks to such qualities as conciliarism (sobornost), compassion (sostradanie), and finally to the practical, active nature of the Russian metaphysical mind.

"Either Oblomov, or revolution"23 (Semenova, 1990:107) is Semenova's paradigm of the Russian character. According to her, "both the West and the East do not just simply lie in the Russian person, some kind of synthesis has occurred here"24 (p. 97). This synthesis of the West and the East in the Russian character, which was expressed more or less definitively in the "creators of the nation", has already been completely and accurately defined in the doctrine of the "common task"25 (p. 98). It is true that this doctrine was not heard by many, but the important thing is that "this doctrine exists, and this collossal fact outweighs the years and centuries of historical wanderings, sins and mistakes of the people"26 (p. 98). But long before Fedorov's 'slavic soul' had started its search for the spiritual, it had found its expression in the apocrypha "The passing of Our Lady through purgatory" (Khozhdenie bogoroditsy po mukam). Semenova (1990:98) draws a comparison with Dante's Divina Commedia as the West's version of the same plot, and concludes:

How different the two 'purgatories' are! The first one, the Western Catholic one: a gloating visit, a meditative inspection with the placid constatation: thus it is, and always will be! The second one is commiserating and effective because it cuts through the thick darkness with a ray of hope and relief. 27

Thus the Russian national character is drawn into the spiritual Oblomov's side of the paradigm, and Stoltz as the Catholic West is the attribute of spiritual passivity. Therefore the Russian national character overcomes the Western character even on the 'lazinessindustry' substructure of the paradigm. Spiritually, and metaphysically, it is superior to its Western counterpart.

A polar interpretation of Fedorov's teachings is given by critic Yury Barabash (1990:180), who creates a dichotomy spiritual-earthly by juxtaposing examples of Gogol and Fedorov. In an article with a title which is characteristic for today's criticism: "Gogol: Meditations on Easter day. On rereading Selected passages from my correspondence with friends, the critic of the Literaturnaya Rossiya brand states that Gogol's spiritual Christianity is superior to Fedorov's preoccupation with this world, and on Easter day (the day the article was published) it appeals more to the Russophilic author.

\footnotetext{
23"ili Oblomov, ili revolytsiya"

24"I zapad, i vostok ne prosto lezhat v russkom cheloveke, tut proizoshel nekiy sintez".

25" Vyrazilsya bolee-menee opredelenno $v$ tvortsakh natsii, $i$, nakonets uzhe sovershenno tochno vyrazilsya v uchenii 'vseobshchego dela'".

${ }^{26 m}$ No ved' ono est', i etot gigantskiy fakt perevesivaet gody i veka istoricheskoy maiyi bluzbdaniy, grekhov, oshibok naroda".

27"Kakie dva raznykh 'khozhdeniya po mukam'!" Pervoe, zapadnokatolicheskoe: zloradnoe viziterstvo, sozertsatel'naya inspekciya dlya spokoynoy konstatacii: tak est' i budet vsegda! Vtoroe soboleznuyushchee $\mathrm{i}$ deystvennoe ottogo prorezayushchee luchom oblegcheniya $\mathrm{i}$ nadezhdy t'mu besprosvetnuyu."
} 


\subsection{Diasporic nature of contemporary Russian culture}

What then is being coined in today's literary struggle? There appears to be a new overtone given to the problem of the Russian national character - the overtone of Russian culture as being more than national culture. Following the 1987-89 period of panhumanist values, and amidst today's national awareness and its spiritual and metaphysical self-analysis, with such diverse concepts as self-consciousness and service - there appears to be a concept of diaspora (rasseyanie) in the making, i.e. there is emerging the theme of the diasporic nature of Russian culture today. And indeed, after the unification of the two Russian literatures on the pages of Soviet literary periodicals, after it had become clear that a Russian writer can belong to more than one culture (Nabokov and Brodsky), it became possible to speak of Russian culture as being more than 'national culture'. Vyacheslav Ivanov (1990:233) in "The problem of Russian culture's rebirth affects very many nationalities", speaks of such a new stage:

In relation to Russian culture the word 'national' is no longer fully adequate. We, the Russians, find ourselves on the road to that which affects the whole world. Our culture is turned to God, i.e. towards that which is more important than our local problems ${ }^{28}$

Russian culture, literature, and thought have become a "form of confession" (forma ispovedaniya); Ivanov (1990:232) knows no "territorial boundaries anymore" - it has left its own confines to enter the world stage and to make a contribution to world culture. In this new hypostasis it is comparable to Buddhism, which was born in one country but became a universal religion. This new form of cultural messianism has no territorial pretentions, and Ivanov (1990:233) ascribes the same significance to the Russian language as to English:

The English language is developing, is enriching the cultures of other peoples thanks to the fact that it is not bound to one territory. And it seems to me this should be correlated with the future of the Russian language. 29

After all, the range of the Russian language's use is just as large as that of English.30

Mikhail Gasparov(1990:74), in his "Russian culture at the crossroad of opinions" states:

If our Russian culture is worth anything, then its imprint will be made on everything we do as Europeans and inhabitants of the world. ${ }^{-3 i}$

If the period of $1988 / 89$ was marked by the coinage of the concept pan-humanism, which helped to cultivate tolerance towards the despised West, then the most recent period $(1989 / 90)$ is marked by an attempt to put an end to the territorial limits of Russian culture, language, and literature. This trend demonstrates a desire to belong to and to be accepted

\footnotetext{
28- Po otnosheniyu $k$ russkoy kul'ture slovo 'natsional'noe' uzhe ne vpol'ne adekvatno. My, russkic, nakhodimsya na puti $k$ tomu, chto kasaetsya usego mira. Nasha kul'tura povernuta $k$ Bogu, to est' k tomu, chto yavno bol'she chem nashi mestnye, zdeshnic problemy."
}

${ }^{29 m}$ Angliyskiy yazyk razvivaetsya, obogashchaet kul'turu drugikh narodov blagodarya tomu, chto on ne privyazan $\mathbf{k}$ odnoy territorii. I, mne kazbetsya, nado by eto sootnesti s budushchim russkogo yazyka."

${ }^{30}$ "Ved' diapazon upotrebleniya russkogo tak zhe velik, kak i diapazon angliyskogo."

${ }^{31}$ "Esli nasha russkaya ku'tura chego-to stoit, to otpechatok ee budet na vsem, chto my budem delat' kak evropeytsy i kak zhiteli zemnogo shara." 
by the West. The latter does not mean the absorption, but rather the preservation of all the 'original' (samobytnye) elements of Russian culture in a diasporic pattern. This includes the preservation of Russianness and of national self-consciousness. It is at the latter point that the politically diverse groups of today's literary camps meet.

\section{Conclusion}

As far as the role of literary criticism in tomorrow's Soviet Union is concerned, all indications show that it will retain its specific social character. The results of the sociologist Shvedov's latest investigations, published in his "What next?" (Shvedov, 1989:30), show that the role of returned literature will be to continue to preserve society from 'social and political blindness'. Two leading scholars, Lidiya Ginzburg and Anatoly Bocharov, have reaffirmed the central importance of literature and literary criticism in future socioeconomic and political debates. In an interview given in Literaturnaya Gazeta with the characteristic title "The literary process today and tomorrow" (Ginsburg \& Bocharov, 1990:5), both academics stress that there never existed and never will exist a "literature without ideas" in Russian society. The most talented pupil of Boris Eykhenbaum and Yury Tynyanov, Lidiya Ginzburg, stated: "Today there is simply no problematics for aesthetically oriented literary criticism"32 (Ginzburg \& Bocharov, 1990:5). Even academic literary scholarship, according to Ginzburg, projects contemporary social and political problems into former centuries. Thus, the social deconstruction of the literary heritage of the past is likely to remain a tool, not only for Soviet literary criticism, but also for its academic counterpart, literary scholarship.

\section{References}

Afanasiev, Ju. (ed.) 1988. Inogo ne dano. Moscow : Progress.

Astafiev, V. 1990. Vo chto veril Gogol? Moskva, 4:182-190.

Barabash, Yu. 1990. Gogol: razdum'ya v svetly prazdnik. Perechityvaya Izbrannye mesta iz perepiski s dnuz'yami. Literatumaya Rossiya, 15:180.

Berdiaev, 1989. On the religious significance of Leo Tolstoy. Voprosy Literatury, 4:150-160.

Besançon, A. 1984. Russkoe proshloe i sovetskoe nastoyashchee. London: Overseas Publications.

Boranova-Gonchenko, L. 1989. Ne son, a bessonnitsa. Literatumaya Rossiya, 52:15.

Bulgakov, S. 1989. My motherland. Novy Mir, 10:180-189.

Chuprinin, S. 1989. Neproshedshee vremya. Voprosy Literatury, 12:3-23.

Dewyatko, I. F. and Sveryev, S. 1990. Zhurnal i ego chitateli. Voprosy Literatury:14.

Epshtein, M. 1989. Son i boy (Oblmov i Korchagin). Iskusstvo Kino, 7:31-41.

Fedotov, G. 1990. Stat'i o kul'ture. Voprosy Literatury, 2:210-215.

Gasparov, M. 1990. Russkaya kul'tura. Voprosy Literatury, 2:74-76.

Ginzburg, L. \& Bocharov, A. 1990. Literaturny protsess segodnya i zavtra. Literatumaya Gazeta, 27:5.

Ivanov, V. 1990. Problema vozrozhdeniya russkoy kul'tury. Druzhba narodov, 1:226-238.

Kantor, V. 1989. Dolgiy navyk ko snu. (Razmyshlenie o romane IA. Goncharova 'Oblomov').

Sovremennoe prochtenie klassiki. Voprosy Literatury, 1:160-189.

Karyakin, Ju. 1989. Dostoevsky i kanun XXI veka. Znamya, 6:239-240.

Latynina, A. 1990. Solzhenitsyn i my. Novy Mir, 1:249.

Leontiev, K. 1989. Analiz, stil' i veianie. O romanakh gr. L.N. Tolstogo. Voprosy Literatury, 12.

Leonticv, K. 1990. Continued Voprosy Literature, 1: 170-189.

Loshchits. Yu. 1986. Goncharov. ZHZL. Moscow : Molodaya Gvardiya.

Mochulskii, K. 1989. Dukhovnyi put, Gogolia. Voprosy Literatury, 11:106-122.

${ }^{32 n}$ Segodnya dlya kritiki s preobladaniem esteticheskogo nachala prosto net problematiki". 
Mondry, H. 1989. Antisemitic trends in Soviet Dostoevsky scholarship of the Brezhnev era. In: Musiker, R. \& Sherman, J. (ed.) Waters out of the well. Essays in Jewish Studies. Johannesburg : University of the Witwatersrand.

Napolova, T. 1990. Preemstvennost' zla. Nash Sovremennik, 1:169-189.

Nekolyukin,A. 1990. Vasily Vasil'evic Rozanov. Znanie, 9:1-30.

Rozanov, 1989. The Russian Nile. Nory Mir, 7:188-236.

Semenova, S. 1982. N.F. Fedorov i ego filosofskoe nasledie. In: Fedorov, N.F. Sachineniya. Moscow : Mysl'.

Semenova, S. 1990. Opravdanie Rossii - (eskiz natsional'noy metafiziki). Voprosy Literatury, 1:96-117.

Shalamov. V. 1989. Varlam Shalamov o Literature. Voprosy Literctury, 5:232-253.

Shreyder, Yu. 1989. Soznanie i ego imitatsiya. Novy Mir, 11:114-118.

Shvedov, S. 1989. Chto dal'she?. Literatumoe Obozrenie, 6:30-32.

Solovev, V. 1990. Towards a characterisation of the Russian mind. Novy Mir, 1:200-220.

Tarasov, V. 1990. Urok iz klassiki : Dostoevsky i Sovremennost'. Moskva, 5:300.

Turbin, V. 1989. Syn otechestva - K 175-letiyu M. Yu. Lermontova. Novy Mir, 10:258.

Zaslavskaya, T. 1988. O strategii sotsial'nogo upravleniya perestroykoy. In: Inogo ne dano. Moscow : Progress Publishers.

Zenkin, S. 1990. Svyashchenno li svyashchennoe?" Polemicheskie zametki ob odnoy esteticheskoy traditsii. Literatumoe Obozrenie, 7:90-99.

Zolutusski, I. 1990. Moskva, 2:195. 